\title{
Harmonisasi Kitab Undang-undang Hukum Pidana dan Legal Culture di Indonesia: Penanganan Zina dan Permasalahannya
}

\author{
Harmonization of the Criminal Code and Legal Culture in Indonesia: The \\ Handling of Adultery and Its Problems
}

\section{Indung Wijayanto ${ }^{1}$, Cahya Wulandari ${ }^{2}$}

1. Universitas Negeri Semarang, Indonesia. E-mail: indungwijayanto@mail.unnes.ac.id

2. Universitas Negeri Semarang, Indonesia. E-mail: cahyawulandari@mail.unnes.ac.id

\begin{tabular}{l}
\hline ARTICLE INFO \\
\hline Keywords: \\
Adultery; \\
Code Penal; \\
Legal Culture \\
\\
\hline
\end{tabular}

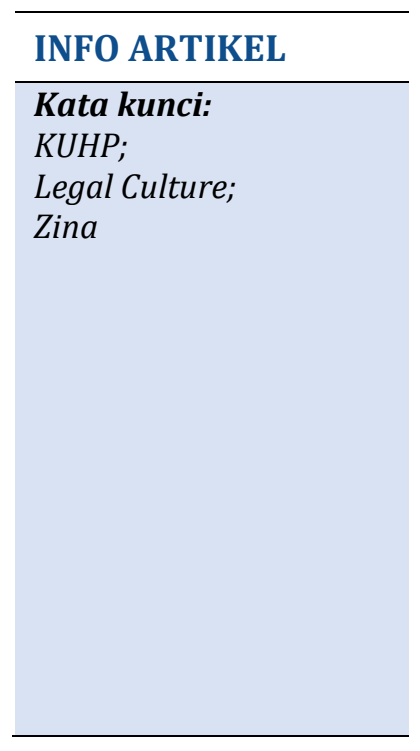

\section{ABSTRACT}

This research aims to find the existence of legal culture of Indonesian society in tackling the adultery and solution of problems in the eradicate of adultery. The method used is a normative juridical approach with qualitative research types. Although there have been rules of positive criminal law governing the crime of adultery, it has not yet accommodated the adultery that occurred between a man and a woman who was not bound in marriage. In order to solve the adultery problem in the community, people use customary law and village regulations. If it does not have customary law and village regulations, the perpetrator is handed to the police. Thus, a renewal in criminal law is required to accommodate the conditions of adultery in a community that is not fulfilled by the current Penal Code of Indonesia.

\footnotetext{
ABSTRAK

Penelitian ini bertujuan untuk menemukan harmonisasi antara Kitab Undang-Undang Hukum Pidana dan legal culture dalam penegakan pasal zina beserta permasalahannya. Metode yang digunakan adalah pendekatan yuridis normatif dengan jenis penelitian kualitatif. Meskipun sudah ada aturan hukum pidana positif yang mengatur terkait tindak pidana zina, namun belum bisa menampung semua permasalahan yang terjadi di Indonesia tentang zina. Aturan terkait zina yang belum bisa tertampung adalah aturan mengenai zina yang terjadi antara seorang laki-laki dan seorang perempuan yang tidak memiliki ikatan perkawinan dengan siapa pun. Sehingga guna menyelesaikan permasalahan yang ada dalam masyarakat, masyarakat menggunakan hukum adat yang mereka pegang teguh sebagai pedoman dan panduan dalam menjalankan kehidupan bermasyarakat, berbangsa dan bernegara. Dengan demikian, diperlukan suatu pembaharuan dalam hukum pidana guna menampung permasalahanpermasalahan yang terjadi di masyarakat yang tidak dapat terpenuhi oleh Kitab Undang-Undang Hukum Pidana yang berlaku saat ini.
} 


\section{Pendahuluan}

Kitab Undang-undang Hukum Pidana (KUHP) yang berlaku di Indonesia saat ini adalah warisan dari Belanda. Produk hukum suatu negara mencerminkan ideologi atau nilai-nilai yang dianut oleh negara tersebut. Begitu pula KUHP, ia mencerminkan ideologi atau nilainilai yang ada di negara Belanda yang berideologi liberal. Tentu saja, ada beberapa peraturan di KUHP tidak sesuai dengan nilai-nilai negara Indonesia. Hal tersebut menjadi salah satu alasan untuk dilakukannya pembaharuan dalam KUHP, yaitu membentuk KUHP yang mengandung nilai-nilai dan norma-norma di dalam masyarakat yang merupakan budaya Bangsa dan Negara Indonesia. Di mana nilai-nilai tersebut telah berakar, tumbuh dan berkembang di masyarakat Indonesia serta menjadi dasar pedoman masyarakat Indonesia dalam menjalankan kehidupan yang bermasyarakat, berbangsa dan bernegara. Nilai-nilai yang hidup di masyarakat Indonesia tersebut adalah nilai ketuhanan, nilai kemanusiaan, nilai persatuan, nilai musyawarah, dan nilai keadilan. Kelima nilai tersebut ada dalam Pancasila yang kebenarannya diakui, dan menimbulkan tekad untuk dilaksanakan dalam Pancasila yang merupakan kristalisasi nilai-nilai yang kebenarannya diakui, dan menimbulkan tekad untuk dilaksanakan dalam kehidupan sehari-hari ${ }^{1}$.

Salah satu norma yang hendak dilindungi di KUHP adalah norma kesusilaan yang diatur dalam Buku II Bab XIV tentang Kejahatan Kesusilaan dari Pasal 281 sampai dengan Pasal 303 bis dan Buku III Bab VI Pelanggaran Kesusilaan dari Pasal 532 sampai dengan Pasal 547. Norma kesusilaan memiliki kaitan dengan nilai yang benar dan salah dalam berperilaku dan bersikap di masyarakat ${ }^{2}$. Norma kesusilaan di Indonesia bisa saja berbeda dengan negara lain karena perilaku masyarakat dipengaruhi oleh ideologi yang dianut. Indonesia yang berideologi Pancasila, kehidupan warganya tidak dapat terlepas dari nilai ketuhanan. Hal ini berbeda dengan negara berideologi liberal yang memisahkan urusan agama dengan urusan pemerintahan. Begitu pula dengan zina, sebagai salah satu bentuk pelanggaran terhadap norma kesusilaan, terdapat perbedaan antara ruang lingkup zina di KUHP dengan ruang lingkup zina yang ada di Indonesia.

Permasalahan yang ada dalam penelitian ini meliputi tentang bagaimanakah eksistensi antara KUHP dan legal culture di indonesia dalam tindak pidana zina, serta peran legal culture dalam penanganan perkara zina di masyarakat. Berdasarkan permasalahan tersebut maka penelitian ini bertujuan untuk menemukan eksistensi antara KUHP dan Legal Culture (hukum materiil) di Indonesia dalam penegakan Pasal Zina di KUHP. Selain itu untuk mengetahui Peran Hukum Materiil dalam Penanganan Perkara Zina di Masyarakat.

1 Aminullah, "Inplementasi Nilai-Nilai Pancasila Dalam Kehidupan," PKPSM IKIP Mataram 3, no. 1 (2015): 620.

2 Asmara \& Rasyid, "Perlindungan Hukum Terhadap Anak Perempuan Korban Kejahatan Kesusilaan di Kota Lhokseumawe," Jurnal Ilmu Hukum 3, no. 2 (2004): 205. 


\section{Metode}

Jenis metode penelitian yang digunakan adalah penelitian hukum normatif. Penelitian hukum normatif adalah suatu proses untuk menemukan suatu aturan hukum, prinsipprinsip hukum, maupun doktrin-doktrin hukum untuk menjawab permasalahan hukum yang dihadapi. ${ }^{3}$ Penelitian hukum normatif dilakukan untuk menghasilkan argumentasi, teori atau konsep baru sebagai gambaran dalam menyelesaikan masalah yang dihadapi. ${ }^{4}$

Peneliti menggunakan pendekatan kualitatif dikarenakan adanya keinginan untuk memahami dan mengungkap harmonisasi antara KUHP dan Legal Culture di Indonesia dalam penegakan pasal zina beserta permasalahannya. Data yang digunakan terkait dengan penelitian ini lebih banyak menggunakan data sekunder. Selain data sekunder, peneliti juga menggunakan data primer sebagai penunjang.

\section{Eksistensi antara KUHP dan Legal Culture di Indonesia dalam Tindak Pidana} Zina

Kitab Undang-undang Hukum Pidana Indonesia, yang merupakan peninggalan penjajah Belanda, mengatur mengenai perzinaan di Pasal 284 KUHP. Tindak pidana zina menurut Pasal 284 KUHP meliputi:

1. seorang laki-laki yang telah kawin yang melakukan hubungan badan dengan bukan pasangan sahnya,

2. seorang wanita yang telah kawin yang melakukan hubungan badan dengan bukan pasangan sahnya,

3. seorang laki-laki yang turut serta melakukan hubungan badan dengan seorang wanita yang telah kawin;

4. seorang wanita yang tidak kawin yang turut serta melakukan hubungan badan dengan seorang laki-laki yang telah kawin.

Syarat lain yang perlu diperhatikan agar perbuatan hubungan kelamin antara seorang pria dengan seorang wanita yang salah satu atau keduanya telah kawin dapat disebut sebagai delik perzinaan menurut KUHP adalah bahwa tidak adanya persetujuan di antara suami istri itu. Artinya jika ada persetujuan di antara suami dan istri, misal suami yang bekerja sebagai muncikari dan istrinya menjadi pelacur bawahannya maka perbuatan semacam itu bukanlah termasuk perbuatan zina ${ }^{5}$.

Tindak pidana zina berdasarkan Pasal 284 ayat (2) dan ayat (3) KUHP merupakan delik aduan absolut dimana penuntutan hanya dapat dilakukan dengan didahului pengaduan oleh pihak suami atau istri yang merasa dirugikan. Apabila pasangan tersebut berlaku Pasal 27 Burgerlijk Wetboek maka dalam tenggang waktu tiga bulan diikuti dengan

Peter Mahmud Marzuki, Penelitian Hukum (Jakarta: Kencana, 2008), 35.

4 Yulianto Achmad dan Mukti Fajar, Dualisme Penelitian Hukum Normatif \& Empiris (Yogyakarta: Pustaka Pelajar, 2010), 48.

5 Lamintang, Delik-delik Khusus: Tindak Pidana-Tindak Pidana yang Melanggar Norma-norma Kesusilaan dan Norma-norma Kepatutan (Bandung: Mandar Maju, 1990). 
permintaan bercerai atau pisah-meja dan ranjang karena alasan pasangannya telah berzina. Pengaduan tersebut tidak diindahkan selama perkawinan belum diputuskan karena perceraian atau sebelum putusan yang menyatakan pisah meja dan tempat tidur menjadi tetap.

Berdasarkan Pasal 284 KUHP dapat dilihat bahwa perzinaan dalam KUHP berkaitan dengan Pasal 27 Burgerlijk Wetboek atau Kitab Undang-Undang Hukum Perdata. Pasal 27 Kitab Undang-Undang Hukum Perdata menyatakan bahwa seorang lelaki hanya boleh terikat perkawinan dengan satu orang perempuan saja, dan begitu pula sebaliknya, seorang perempuan hanya boleh terikat perkawinan dengan satu orang lelaki saja. Pasal 27 Kitab Undang-Undang Hukum Perdata menganut asas monogami mutlak dalam perkawinan, dimana seseorang hanya boleh memiliki satu pasangan saja. Hal ini sejalan dengan ajaran agama Katolik yang menganut asas monogami mutlak dalam perkawinan. Agama Katolik adalah agama mayoritas yang dianut di negara Belanda sebagai negara pembentuk KUHP Indonesia yang berlaku saat ini. Apabila kita berpandangan pada Pasal 284 KUHP, tanpa mengaitkannya dengan Pasal 3 ayat (2) UU No.1 Tahun 1974 tentang Perkawinan yang memungkinkan kepada seorang suami untuk berpoligami, maka seorang laki-laki yang beristri lebih dari satu bisa dikatakan telah melakukan zina meskipun istri yang kedua dinikahinya secara resmi.

Ruang lingkup tindak pidana zina dalam Pasal 285 KUHP tentu saja berbeda dengan apa yang dianggap sebagai zina bagi masyarakat Indonesia. Hal tersebut dapat dilihat dalam berbagai kasus di bawah ini:

1. Dua mahasiswa yang diduga kuat mengenyam pendidikan di Institut Agama Islam Negeri (IAIN) Salatiga itu ketahuan berbuat tidak senonoh di dalam Masjid At-Taqwa yang terletak di Desa Sraten, Kecamatan Tuntang, Kabupaten Semarang. Keduanya kemudian diserahkan warga ke kepolisian untuk menjalani pemeriksaan. Kedua mahasiswa itu hanya dikembalikan ke orang tua dan hanya dikenai wajib lapor ke Mapolres dua kali dalam sepekan ${ }^{6}$.

2. Sepasang kekasih yang masih berumur 18 tahun dan 15 tahun tertangkap basah melakukan hubungan suami istri di dalam sebuah mobil yang terparkir di rumah Bupati Kupang, Jalan RA Kartini Kelurahan Kelapa Lima, Kecamatan Kelapa Lima, Kota Kupang pada Rabu tanggal 17 Juli 2019. Pelaku lalu dibawa warga ke Mapolres Polres Kupang Kota 7.

3. Sepasang kekasih tertangkap basah sedang berhubungan badan di sebuah wisma di Meulaboh, Aceh Barat. Mereka kemudian diserahkan kepada petugas, dan terancam hukuman cambuk 100 kali ${ }^{8}$.

6 Reza Gunadha, "Ketagihan, Mahasiswa IAIN Kembali Mesum di Dalam Masjid," Suara, last modified April 2018, diakses Februari 14, 2020, https://www.suara.com/news/2018/04/16/191500/ketagihanmahasiswa-iain-kembali-mesum-di-dalam-masjid?page=all.

7 Hari Susmayanti, "Sepasang Kekasih di Kupang Tertangkap Berhubungan Badan di Dalam Mobil," Pos Kupang (Yogyakarta, 2019).

8 Raja Umar, "Tepergok Berhubungan Seks Sepasang Kekasih Terancam Hukuman Cambuk 100 Kali," Kompas.com, last modified Januari 2016, diakses Februari 15, 2020, 
Dari beberapa kasus di atas dapat dilihat bahwa cakupan tindak pidana zina yang ada di masyarakat meliputi persetubuhan yang dilakukan oleh mereka yang ada di luar perkawinan yang sah. Artinya, tindak pidana zina tersebut bisa dilakukan oleh mereka yang belum menikah maupun oleh mereka yang sudah terikat perkawinan yang sah namun bersetubuh dengan bukan pasangan perkawinannya tersebut.

Perbedaan cakupan tindak pidana zina dalam hukum tidak tertulis di masyarakat dengan Pasal 284 KUHP tersebut dapat dipahami karena adanya perbedaan pandangan hidup, nilai dan norma yang dianut antara Indonesia dengan Belanda. Pemerintah Belanda sebagai pembuat KUHP, menganut ideologi liberal dan asas monogami mutlak dalam perkawinan. Dalam pandangan negara yang berideologi liberal, hak-hak dan kebebasan sangat dijunjung sangat tinggi. Mereka memandang hubungan seksual itu bersifat individual, bebas, dan tanpa paksaan (suka sama suka). Hubungan seksual yang demikian dipandang wajar dan tidak tercela. Perzinaan dan lembaga perkawinan dipandang bersifat sangat pribadi. Sehingga wajar, jika perzinaan dipandang sebagai delik aduan di negara yang berideologi liberal 9 . Meskipun hubungan seksual di luar perkawinan dianggap sebagai hal wajar, namun mereka terikat pada asas monogami mutlak.

Norma kesusilaan di negara berideologi liberal tentu saja berbeda dengan norma kesusilaan di Indonesia yang menganut ideologi Pancasila. Semua aspek kehidupan bangsa Indonesia tidak terlepas dari nilai-nilai yang terkandung dalam Pancasila, yaitu nilai ketuhanan, nilai kemanusiaan, nilai persatuan, nilai musyawarah, dan nilai keadilan. Kelima nilai tersebut merupakan panduan hidup dalam masyarakat yang terbingkai dalam hukum adat 10 .

Perbuatan zina bertentangan dengan nilai ketuhanan karena semua ajaran agama yang dianut di Indonesia melarang perbuatan zina, baik yang dilakukan oleh orang yang terikat perkawinan maupun belum terikat perkawinan. Kitab suci agama Hindu, yaitu anawadharmasastra, Sarasamuscaya, dan Parasaradharmasastra, menjelaskan bahwa zina adalah dosa yang tidak terampuni selama keadaan cuntaka (keadaan seseorang dalam kondisi tidak suci) belum terhapus. Zina dalam kitab tersebut meliputi perbuatan zina yang dilakukan oleh orang yang terikat perkawinan atau belum. Definisi zina dalam agama Katolik meliputi perbuatan zina yang dilakukan oleh orang yang terikat perkawinan. Definisi zina tersebut diatur dalam Katekismus Gereja Katolik 2380 dan 2381. Ajaran Kristen melarang zina yang dilakukan oleh orang yang belum menikah maupun sedang terikat perkawinan. Dalam Korintus 7:9 disebutkan bahwa apabila tidak dapat menguasai diri, baiklah mereka kawin, lebih baik kawin dari pada hangus karena hawa nafsu. Kitab Ibrani 13:4 menyatakan supaya semua orang menghormati perkawinan dan jangan mencemari tempat tidur, sebab orang-orang sundal dan perintah akan dihukum Allah.

https://sains.kompas.com/read/2016/01/29/21210151/Tepergok.Berhubungan.Seks.Sepasang.Kekas ih.Terancam.Hukuman.Cambuk.100.Kali.

9 Barda Nawawi Arief, Bunga Rampai Kebijakan Hukum Pidana (Jakarta: PT. Citra Aditya Bakti, 1996).

10 Kuswardani dkk, "Hak Reproduksi Perempuan dan Hukum Pidana," Halu Oleo Law Review 3, no. 2 (2019): 220. 
Ajaran Budha tidak menyinggung zina yang dilakukan oleh orang yang belum menikah, namun menyinggung perbuatan zina yang dilakukan oleh orang yang masih terikat perkawinan. Hal tersebut dapat dilihat dalam kitab Suci Hukum Karma yang di uraikan oleh Buddha Sakyamuni yang menyatakan seseorang tidak punya jodoh, karena di kehidupan yang lalu ia telah berzina dengan istri orang. Dalam Islam, perbuatan zina tidak hanya meliputi zina yang dilakukan orang yang terikat perkawinan namun juga zina yang dilakukan orang yang belum menikah. Hal tersebut sebagaimana disebutkan dalam hadis yang diriwayatkan H.R. Muslim bahwa lelaki belum menikah yang berzina dengan wanita belum menikah, masing-masing dicambuk seratus kali dan diasingkan selama satu tahun, sedangkan orang yang telah menikah melakukan zina, dicambuk seratus kali dan dirajam. Ensiklopedi Hukum Pidana Islam menyebutkan pengertian zina menurut beberapa mazhab yang maknanya kurang lebih sama, yaitu persetubuhan antara laki-laki dan perempuan yang dilakukan oleh mukalaf yang tidak terikat oleh perkawinan yang sah ${ }^{11}$.

Pandangan masyarakat Indonesia mengenai zina tidak jauh berbeda dengan pandangan Sahetapy yang menyatakan perbuatan bersetubuh yang tidak sah berarti persetubuhan yang bukan saja dilakukan oleh suami atau istri di luar lembaga perkawinan, tetapi juga persetubuhan yang dilakukan oleh pria dan wanita di mana keduanya belum menikah, kendatipun sudah bertunangan. Sah di sini harus ditafsirkan sah dalam ruang lingkup lembaga perkawinan. Sehingga zina meliputi pula fornication yaitu persetubuhan yang dilakukan secara suka rela antara seorang yang belum menikah dengan seseorang dari sex yang berlawanan (yang belum menikah juga). Meskipun persetubuhan itu bersifat volunter, atas dasar suka sama suka, namun perbuatan bersetubuh itu tetap tidak sah. Menurut anggota masyarakat, persetubuhan yang sah hanya dilakukan dalam lembaga perkawinan. Dengan demikian pengertian berzina mencakup pengertian overspel, fornication dan prostitusi ${ }^{12}$.

KUHP yang berlaku saat ini adalah warisan Belanda sehingga pengaturan tindak pidana zina di KUHP jelas tidak sesuai dengan nilai-nilai yang hidup di masyarakat Indonesia atau bertentangan dengan hukum asli Indonesia. Hukum asli Indonesia yang dibuat oleh masyarakat Indonesia secara turun temurun berdasarkan value consciousness mereka yang termanifestasi dalam cara hidup sehari-hari ${ }^{13}$. Kondisi demikian oleh kongres PBB dinyatakan sebagai faktor yang berkontribusi untuk terjadinya kejahatan ("a contributing factor to the increase of crime") bahkan, dinyatakan bahwa kebijakan pembangunan (termasuk bidang hukum) yang mengabaikan nilai-nilai moral dan kultural antara lain dengan masih diberlakukannya hukum asing warisan zaman kolonial ${ }^{14}$. Karena Pasal 284 KUHP tidak sesuai dengan nilai-nilai masyarakat Indonesia, maka Pasal 284 KUHP tidak efektif untuk mengatasi permasalahan seks di luar nikah yang terjadi di Indonesia. KUHP

11 Syamsul Huda, "Zina Dalam Perspektif Hukum Islam Dan Kitab Undang-Undang Hukum Pidana," Jurnal Studia Islamika 12, no. 2 (2015): 381.

12 Sahetapy dan B. Mardjno Reksodiputro, Paradoks dalam Kriminologi (Jakarta: Rajawali, 1989).

13 Fransiskus Saverius Nurdin, "Masyarakat Hukum Adat Sebagai Entitas Dasar Pembentuk Peradaban Bangsa," Law Review XIX, no. 2 (2019): 121.

14 Barda Nawawi Arief, Kapita Selekta Hukum Pidana (Bandung: Citra Aditiya Bakti, 2002). 
tidak mengatur atau memberi ancaman pidana bagi pria maupun wanita belum terikat perkawinan yang melakukan perbuatan zina. Oleh karena itu maraknya perbuatan zina di luar perkawinan sulit untuk diberikan sanksi pidana apabila hal tersebut dilakukan atas dasar suka sama suka dan tidak adanya unsur paksaan dari salah satu pihak. Sebagai konsekuensinya, kasus perzinaan di luar nikah yang dilakukan masih banyak. Hal tersebut dapat dilihat dari hasil penelitian yang dilakukan oleh Reckitt Benckiser Indonesia pada tahun 2019 yang menyatakan bahwa 33 persen remaja Indonesia telah melakukan hubungan badan di luar pernikahan ${ }^{15}$. Ini juga menunjukkan pergeseran nilai kesusilaan dalam masyarakat telah terjadi, yang dapat dilihat dari perilaku sebagian pelaku zina yang semakin berani dan tidak tercermin rasa bersalah ${ }^{16}$. Kasus seperti ini sekarang banyak terjadi sebagai akibat dari pergaulan bebas antara laki-laki dan perempuan atau juga karena kisah cinta antara dua sejoli tidak direstui oleh orang tua sehingga keduanya nekat melakukan hubungan kelamin supaya nanti kalau sudah hamil mau tidak mau hubungan cinta mereka akan direstui juga oleh keluarga, atau juga terjadi karena seorang wanita sudah terlanjur hamil sebagai akibat dari perkosaan atau juga akibat lelaki yang menghamilinya kabur tanpa mau bertanggung jawab ${ }^{17}$.

Salah satu masalah yang belum diatur dalam Undang-Undang khususnya KUHP pada saat ini tentang bagaimana pertanggungjawaban hukum terhadap seorang laki-laki yang melakukan tipu daya kepada seorang perempuan agar mau melakukan hubungan badan di luar perkawinan. Kemudian, wanita tersebut hamil sedangkan laki-laki tersebut tidak mau bertanggungjawab. Wanita tersebut otomatis tidak bisa menuntut laki-laki yang telah mengajaknya berhubungan badan.

\section{Peran Legal Culture (Hukum Materiil) dalam Penanganan Perkara Zina di Masyarakat}

Legal culture adalah hukum tidak tertulis yang hidup di masyarakat. Beberapa masyarakat adat di Indonesia memiliki hukumnya sendiri dalam menangani pelaku zina, baik zina antara orang yang tidak terikat tali perkawinan maupun yang sudah terikat tali perkawinan namun berhubungan badan dengan bukan pasangannya yang sah. Berikut ini adalah legal culture yang mengatur mengenai larangan zina:

1. Jenis sanksi adat untuk pelaku zina di masyarakat Kenagarian Garagahan Kecamatan Lubuk Basung, Sumatera Barat:

15 Giovani Dio Prasasti, “Riset: 33 Persen Remaja Indonesia Lakukan Hubungan Seks Penetrasi Sebelum Nikah," Liputan6.com, last modified 2019, diakses Februari 21, 2020, https://www.liputan6.com/health/read/4016841/riset-33-persen-remaja-indonesia-lakukanhubungan-seks-penetrasi-sebelum-nikah\#.

16 Neng Djubaedah, Perzinaan Dalam Peraturan Perundang-Undangan di Indonesia Ditinjau Dari Hukum islam, 1 ed. (Jakarta: Kencana, 2010).

17 Saiful Millah, "Pernikahan Wanita yang Hamil di Luar Nikah dan Akibat Hukumnya: Telaah atas Dualisme Fikih dan Kompilasi Hukum Islam,” Misykat 02, no. 02 (2017): 52. 
a. Dibuang dari daerah asal pelaku zina

Dibuang dari daerah asal pelaku zina bentuknya bisa 1) pelaku zina diusir dari daerah dan dari komunitasnya sesuai hukum adat sampai batas yang telah ditentukan. Apabila pelaku zina tersebut telah berkelakuan baik menurut komunitas atau masyarakat setempat maka pelaku tersebut dapat kembali ke daerahnya. 2) pelaku zina dibuang dari daerahnya sesuai hukum adat bersama seluruh anggota keluarga inti atau Seinduk, karena masyarakat setempat menganggap bahwa anggota keluarga pelaku zina telah berusaha untuk menutupnutupi atau melindungi perbuatan zina si pelaku. 3) pelaku zina dibuang dari daerahnya berdasarkan hukum adat karena pelaku telah berzina dengan orang yang menganut agama berbeda dari dirinya. 4) pelaku zina dibuang dari daerahnya sesuai hukum adat bersama seluruh anggota keluarga besarnya atau keluarga Seandung atau satu keturunan atau satu kaum, karena masyarakat telah menganggap bahwa keluarga besar atau kaum pelaku zina tersebut berusaha untuk menutupi perbuatan zina dari pelaku. 5) pelaku zina dibuang dari daerahnya sesuai hukum adat apabila pelaku zina tidak mampu membayar hukuman denda yang telah disepakati oleh masyarakat adat. 6) pelaku zina diusir dari daerah yang bersangkutan selama-lamanya, sesuai hukum adat. Hal ini berarti pelaku zina tidak boleh kembali ke daerahnya.

b. Hukuman denda

Denda yang dikenakan kepada pelaku zina dapat berupa sejumlah uang atau emas yang telah disepakati oleh masyarakat adat, atau memberi makan kaum pasukuan (beras 1 pikul, 1 ekor jawi, beserta sirih dan carano). Atau pelaku zina harus menyerahkan 5 buah karung semen untuk keperluan pembangunan di daerahnya. Denda 5 buah karung semen dijatuhkan kepada pelaku zina jika perbuatannya masih dapat diterima oleh kaum masyarakat adat. 18

2. Masyarakat Kabupaten Padang Lawas Utara, Sumatera Utara memberi hukuman adat kepada pelaku zina berupa Sappal Dila yaitu pelaku zina dihukum harus memotong seekor kambing atau kerbau atau lembu dan harus disertai dengan mengundang makan semua orang di masyarakat adat untuk melakukan permintaan maaf di muka Harajaon, Hatobangon, ulama dan masyarakat adat Dalihan na Tolu. Di samping hukuman Sappal Dila, laki-laki yang telah berzina diharuskan untuk menikahi wanita pasangan zinanya apabila tidak ada penghalang perkawinan bagi laki-laki tersebut untuk menikahinya. Dan apabila si pelaku zina tidak menaati hukuman adat yang telah dijatuhkan kepadanya maka pelaku zina akan dibondarkon yaitu dikucilkan dari berbagai kegiatan yang diadakan oleh masyarakat adat. Dan sebaliknya apabila pelaku zina, yang tidak menaati hukuman adat, tersebut mengadakan suatu kegiatan di

18 Dkk Bobi Handoko, "Penerapan Sanksi Pidana Adat Terhadap Pelaku Zina di Wilayah Kenagarian Garagahan Kecamatan Lubuk Basung Kabupaten Agam," Jurnal Online Mahasiswa (JOM) Bidang Ilmu Hukum 2, no. 2 (2015): 7-8. 
masyarakat maka ia tidak bisa melaksanakan kegiatan tersebut sesuai dengan tata cara adat setempat 19 .

Berkaitan dengan sanksi adat untuk pelaku zina, Taufik Siregar menyatakan bahwa penerapan hukuman terhadap para pelaku prostitusi, termasuk di dalamnya pelaku zina, sebenarnya jauh lebih efektif jika menyerahkan perkara zina tersebut kepada keluarga juga masyarakat adat dimana pelaku zina berdomisili. Hal ini karena penjatuhan hukuman melalui keluarga dan masyarakat adat jauh memiliki efek jera, jika dibandingkan dengan pemberian hukuman lewat pendekatan hukum formal atau hukum tertulis 20 .

Beberapa desa di Indonesia, yang bukan masyarakat adat, juga membentuk peraturan desa yang berkaitan dengan larangan zina, meskipun ada yang masih berbentuk rancangan. Beberapa peraturan desa tersebut adalah:

1. Rancangan Peraturan Desa Pulau Gadang Kecamatan XIII Koto Kampar Kabupaten Kampar Nomor: 02 Tahun 2014 tentang Penyakit Masyarakat. Larangan berbuat zina diatur di dalam Pasal 7 sebagai berikut:

1) Setiap orang berlainan jenis kelamin dan atau bukan Muhrimnya dilarang tinggal dan atau hidup satu atap layaknya suami istri tanpa diikat oleh perkawinan yang sah berdasarkan Undang-undang yang berlaku.

2) Setiap orang berlainan jenis kelamin dan atau bukan Muhrimnya dilarang bepergian secara bersama baik dalam desa maupun di luar desa terkecuali didampingi oleh salah satu muhrimnya.

3) Setiap orang berlainan jenis kelamin dan atau bukan Muhrimnya dilarang tinggal dan atau menginap satu kamar di hotel dan sejenisnya terkecuali dalam acaraacara keluarga yang bisa dipertanggung jawabkan oleh keluarganya yang dimaksud.

2. Peraturan Desa Betoyoguci Manyar Gresik Nomor 5 Tahun 2016 tentang Kemasyarakatan

Larangan perbuatan zina dalam Peraturan Desa tersebut diatur dalam Pasal 6 ayat (1) yang menyatakan bahwa: "Setiap orang di desa Betoyoguci dilarang melakukan halhal sebagai berikut: perzinaan dan pemerkosaan; perjudian, miras dan narkoba; pencurian dan kejahatan lainnya; membuka warung remang-remang dan sejenisnya; dan hal-hal lain yang meresahkan masyarakat". Pasal 6 ayat (2) mengatur sanksi bagi para pelaku zina. Sanksinya adalah apabila pelakunya belum memiliki keluarga atau belum menikah, maka wajib menikah dengan pasangan zinanya. Selain wajib menikah, laki-laki maupun wanita pelaku zina wajib membayar denda 3 truk pasir. Apabila pelaku zina sudah ada yang berkeluarga atau sudah menikah, maka kedua pelaku zina wajib membayar denda berupa 5 truk pasir".

19 dkk Rahmat Syaputra, "Penerapan Sanksi Pidana Adat Terhadap Pelaku Zina Di Wilayah Kabupaten Padang Lawas Utara," USU Law Journal 7, no. 3 (2019): 174-175.

20 Ibid. 
Yang jadi permasalahan dari Peraturan-peraturan Desa tersebut adalah, berdasarkan Pasal 15 ayat (1) UU No. 12 Tahun 2011 tentang Pembentukan Peraturan Perundangundangan, peraturan desa tidak boleh memuat ketentuan sanksi pidana. Karena berdasarkan Pasal 15 ayat (1) UU No. 12 Tahun 2011 hanya Undang-Undang, Peraturan Daerah Provinsi, atau Peraturan Daerah Kabupaten/Kota yang boleh memuat sanksi pidana. Jadi semua peraturan selain Undang-Undang, Peraturan Daerah Provinsi, atau Peraturan Daerah Kabupaten atau Kota tidak boleh memuat sanksi pidana. Apabila ada peraturan desa yang memuat sanksi pidana maka bertentangan dengan UU No. 12 Tahun 2011. Jadi aturan Pasal 15 UU No. 12 Tahun 2011 jelas menghambat desa dalam membuat peraturan desa yang memberi sanksi denda kepada para pelaku zina. Hal tersebut dikarenakan sanksi denda termasuk salah satu jenis sanksi pidana. Sebuah peraturan desa yang melarang suatu perbuatan, termasuk perbuatan zina, tanpa disertai dengan sanksi jelas tidak akan memiliki arti. Sedangkan, jika desa tidak membuat sebuah peraturan desa yang melarang perbuatan zina, masyarakat akan menjadi resah karena perbuatan zina bisa menjadi semakin banyak di lingkungannya. Oleh karena itu, seharusnya UU No. 12 Tahun 2011 memberikan kelonggaran kepada desa untuk membuat peraturan desa yang memuat sanksi denda bagi pelaku yang melanggar perbuatan yang dilarang di desa.

Rancangan Kitab Undang-Undang Hukum Pidana yang terakhir dirilis pada bulan September 2019 (RUU KHUP 2019) berusaha mewadahi nilai-nilai masyarakat Indonesia mengenai larangan hubungan badan di luar pernikahan. RUU KHUP tersebut mengatur zina di Bagian Keempat Bab XV Buku II tentang Perzinaan. Pasal-pasal yang mengatur tentang perzinaan terdapat dalam Pasal 417 sampai dengan Pasal 419 RUU KHUP 2019. Pasal 417 ayat (1) menyatakan bahwa orang yang bersetubuh dengan orang yang bukan suami atau istrinya dianggap telah melakukan perbuatan zina. Penjelasan Pasal 417 ayat (1) menyatakan bahwa pengertian "bukan suami atau istrinya" meliputi: 1) laki-laki yang memiliki ikatan perkawinan bersetubuh dengan perempuan yang bukan istrinya; 2) perempuan yang memiliki ikatan perkawinan bersetubuh dengan laki-laki yang bukan suaminya; 3) laki-laki yang tidak memiliki ikatan perkawinan bersetubuh dengan perempuan yang memiliki ikatan perkawinan; 4) perempuan yang tidak memiliki ikatan perkawinan bersetubuh dengan laki-laki yang memiliki ikatan perkawinan; atau 5) lakilaki dan perempuan yang masing-masing tidak terikat perkawinan melakukan persetubuhan. Dari bunyi Pasal 417 ayat (1) dan penjelasannya terlihat bahwa pengertian zina dalam RUU KHUP 2019 sesuai dengan pengertian zina dalam konsep agama Islam. Dalam pandangan agama Islam, zina tidak hanya hubungan badan antara orang yang terikat tali perkawinan dengan orang yang bukan suami atau istrinya. Namun juga bisa dilakukan oleh dua orang yang masing-masing belum terikat tali perkawinan yang sah. Pasal 417 ayat (2) mengatur bahwa pelaku zina hanya bisa dituntut apabila ada pengaduan dari istri, orang tua, atau anak. Pasal 418 ayat (1) mengatur tentang larangan orang hidup bersama sebagai suami istri tanpa ikatan perkawinan (kumpul kebo). Pasal 419 mengatur larangan mengenai incest antara anggota keluarga sedarah dalam garis lurus atau ke samping sampai derajat ketiga. 
Pasal 417 dan 418 mengatur zina sebagai delik aduan, dimana pelaku tidak bisa dituntut kecuali atas pengaduan dari orang tua, suami, istri atau anaknya. Pasal 418 ayat (3) menambahkan bahwa kepala desa (atau dengan nama lain) bisa mengadukan orang yang melanggar Pasal 418 ayat (1). Namun pengaduan dari kepala desa tersebut dapat dilakukan sepanjang suami, istri, Orang Tua, atau anak dari pelaku zina tidak keberatan atas pengaduan tersebut. Apabila dikaitkan dengan beberapa contoh kasus zina di atas, maka zina sebagai delik aduan dalam RUU KHUP 2019 sebenarnya tidak sesuai dengan nilai-nilai yang hidup di masyarakat. Dalam contoh kasus tersebut terlihat bahwa masyarakat berperan aktif dalam melaporkan pelaku zina ke kepolisian, meskipun tidak ada pengaduan dari orang tua, suami, istri atau anaknya. Bahkan dalam masyarakat Kenagarian Garagahan Kecamatan Lubuk Basung, Sumatera Barat, keluarga dari pelaku zina juga bisa ikut dikenai sanksi apabila menutup-nutupi atau melindungi perbuatan si pelaku. Hal ini dikarenakan perbuatan zina menurut masyarakat merupakan pelanggaran yang sangat berat.

\section{Kesimpulan}

Peraturan zina dalam Pasal 284 KUHP tidak relevan dengan legal culture di masyarakat karena aturan zina dalam Pasal 284 KUHP hanya berlaku untuk orang yang dalam ikatan perkawinan kemudian berhubungan badan dengan orang yang bukan suami atau istrinya. Sedangkan di masyarakat, zina bisa juga dilakukan oleh orang yang masing-masing tidak ada ikatan perkawinan. Peran legal culture di masyarakat dalam menangani zina berupa pemberian sanksi adat untuk pelaku yang melakukan zina di masyarakat adat dan denda untuk pelaku yang melanggar Peraturan Desa. Sedangkan lingkungan masyarakat yang tidak memiliki hukum adat ataupun peraturan desa, warga menyerahkan para pelaku zina ke kepolisian untuk ditindaklanjuti. Namun, kepolisian tidak bisa menindaklanjuti laporan tersebut karena Pasal 284 KUHP tidak bisa untuk menindak pelaku zina yang tidak dalam ikatan perkawinan. Peraturan desa seharusnya diperbolehkan memuat sanksi denda untuk orang yang melanggar peraturan desa, khususnya dalam hal terjadi zina.

\section{Daftar Pustaka}

Achmad, Yulianto, dan Mukti Fajar. Dualisme Penelitian Hukum Normatif \& Empiris. Yogyakarta: Pustaka Pelajar, 2010.

Aminullah. "Inplementasi Nilai-Nilai Pancasila Dalam Kehidupan." PKPSM IKIP Mataram 3, no. 1 (2015): 620-628.

Asmara \& Rasyid. "Perlindungan Hukum Terhadap Anak Perempuan Korban Kejahatan Kesusilaan di Kota Lhokseumawe.” Jurnal Ilmu Hukum 3, no. 2 (2004): 205.

Bobi Handoko, Dkk. "Penerapan Sanksi Pidana Adat Terhadap Pelaku Zina di Wilayah Kenagarian Garagahan Kecamatan Lubuk Basung Kabupaten Agam." Jurnal Online Mahasiswa (JOM) Bidang Ilmu Hukum 2, no. 2 (2015): 7-8.

Djubaedah, Neng. Perzinaan Dalam Peraturan Perundang-Undangan di Indonesia Ditinjau Dari Hukum islam. 1 ed. Jakarta: Kencana, 2010. 
Gunadha, Reza. "Ketagihan, Mahasiswa IAIN Kembali Mesum di Dalam Masjid." Suara. Last modified April 2018. Diakses Februari 14, 2020. https://www.suara.com/news/2018/04/16/191500/ketagihan-mahasiswa-iainkembali-mesum-di-dalam-masjid?page=all.

Huda, Syamsul. "Zina Dalam Perspektif Hukum Islam Dan Kitab Undang-Undang Hukum Pidana." Jurnal Studia Islamika 12, no. 2 (2015): 381.

Kuswardani dkk. "Hak Reproduksi Perempuan dan Hukum Pidana." Halu Oleo Law Review 3, no. 2 (2019): 220.

Lamintang. Delik-delik Khusus: Tindak Pidana-Tindak Pidana yang Melanggar Normanorma Kesusilaan dan Norma-norma Kepatutan. Bandung: Mandar Maju, 1990.

Marzuki, Peter Mahmud. Penelitian Hukum. Jakarta: Kencana, 2008.

Millah, Saiful. "Pernikahan Wanita yang Hamil di Luar Nikah dan Akibat Hukumnya: Telaah atas Dualisme Fikih dan Kompilasi Hukum Islam.” Misykat 02, no. 02 (2017): 39-76.

Nawawi Arief, Barda. Bunga Rampai Kebijakan Hukum Pidana. Jakarta: PT. Citra Aditya Bakti, 1996.

___. Kapita Selekta Hukum Pidana. Bandung: Citra Aditiya Bakti, 2002.

Nurdin, Fransiskus Saverius. "Masyarakat Hukum Adat Sebagai Entitas Dasar Pembentuk Peradaban Bangsa.” Law Review XIX, no. 2 (2019): 121.

Prasasti, Giovani Dio. "Riset: 33 Persen Remaja Indonesia Lakukan Hubungan Seks Penetrasi Sebelum Nikah." Liputan6.com. Last modified 2019. Diakses Februari 21, 2020. https://www.liputan6.com/health/read/4016841/riset-33-persen-remajaindonesia-lakukan-hubungan-seks-penetrasi-sebelum-nikah\#.

Rahmat Syaputra, dkk. "Penerapan Sanksi Pidana Adat Terhadap Pelaku Zina Di Wilayah Kabupaten Padang Lawas Utara." USU Law Journal 7, no. 3 (2019): 174-175.

Reksodiputro, Sahetapy dan B. Mardjno. Paradoks dalam Kriminologi. Jakarta: Rajawali, 1989.

Susmayanti, Hari. "Sepasang Kekasih di Kupang Tertangkap Berhubungan Badan di Dalam Mobil.” Pos Kupang. Yogyakarta, 2019.

Umar, Raja. "Tepergok Berhubungan Seks Sepasang Kekasih Terancam Hukuman Cambuk 100 Kali." Kompas.com. Last modified Januari 2016. Diakses Februari 15, 2020. https://sains.kompas.com/read/2016/01/29/21210151/Tepergok.Berhubungan.S eks.Sepasang.Kekasih.Terancam.Hukuman.Cambuk.100.Kali. 